\title{
Correction: Targeting the elF4A RNA helicase blocks translation of the MUC1-C oncoprotein
}

\author{
C. Jin · H. Rajabi - C. M. Rodrigo · J. A. Porco Jr · D. Kufe
}

Published online: 13 April 2021

(c) The Author(s), under exclusive licence to Springer Nature Limited 2021

Correction to: Oncogene (2013) 32, 2179-188;

https://doi.org/10.1038/onc.2012.236

The original version of this article contained an error in

Fig. 6c, which does not affect the conclusions of the

research. Following the publication of this article, the authors noted the same image for beta-actin loading was inadvertently included in Fig. $6 \mathrm{c}$ left and right. The corrected version for Fig. $6 \mathrm{c}$ is provided below.

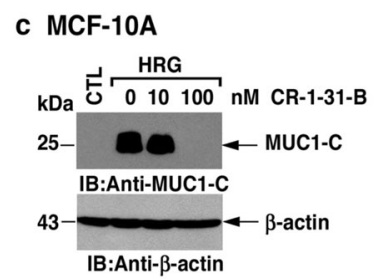

Fig. 6 MUC1-C translation is inhibited by CR-1-31-B in MCF-10A cells. a Structures of the indicated compounds. MCF-10A cells were left untreated (CTL) and stimulated with EGF (b) or HRG (c) in the presence of the indicated concentrations of CR-1-31-B (left) or inactive CR-1- 30-B (right) for $24 \mathrm{~h}$. d MCF-10A cells were stimulated

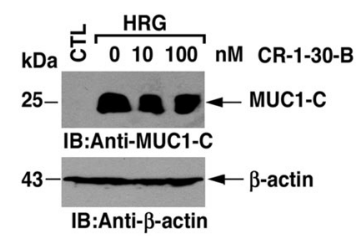

with EGF in the absence (CTL) or presence of $100 \mathrm{nM} \mathrm{CR}-1-31-\mathrm{B}$ or CR-1-30-B for $24 \mathrm{~h}$, reseeded and then counted at $48 \mathrm{~h}$. Viable cell number (mean \pm s.d. of three determinations) was determined by trypan blue exclusion. 